\title{
Treffinger Creative Learning Model with RME Principles on Creative Thinking Skill by Considering Numerical Ability
}

\author{
Sabina Ndiung \\ STKIP Santu Paulus Ruteng, Jalan A. Yani No 10 Ruteng, Flores, Indonesia, \\ punyaku79@gmail.com
}

Nyoman Dantes

Prof., Universitas Pendidikan Ganesha, Indonesia,dantes_nyoman@yahoo.co.id

\section{Made Ardana}

Prof., Universitas Pendidikan Ganesha, Indonesia, ardanaimade@undiksha.ac.id

\section{A. A. I. N Marhaeni}

Prof., Universitas Pendidikan Ganesha, Indonesia,ngurah_marhaeni@yahoo.com

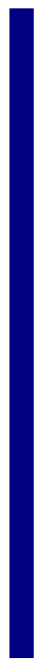

\begin{abstract}
This study aimed at finding out the effect of Treffinger creative learning model with RME principles on creative thinking skills by controlling numerical ability. This study was conducted to the fifth grade students of elementary schools in Manggarai regency using post-test only control group design of experiment. This study involved 101 fifth grade students as sample who were selected by using random sampling technique. The instruments were numeric ability test and creative thinking skill test. Data were analyzed by using ANCOVA aided by SPSS 23.0 program. The results showed that 1 ) the creative thinking skill of the students who learned mathematics Treffinger creative learning model with RME principles was higher than those who learned mathematics through conventional model, 2) the creative thinking skill of the students who learned through Treffinger creative learning model with RME principles was higher than those who learned through conventional learning model, after controlling numeric ability, 3) numeric ability gives a $33,2 \%$ contribution to the students' creative thinking skill. These findings show that Treffinger creative learning model with RME principles has a significant effect on the students' creative thinking skill. Mathematics teachers are suggested to employ this model in developing students' creative thinking skill.
\end{abstract}

Keywords: creative thinking skill, elementary school, numerical ability, RME principles, Treffinger creative learning model

Citation: Ndiung, S., Dantes, N., Ardana, I. M., \& Marhaeni, A. A. I. N. (2019). Treffinger Creative Learning Model with RME Principles on Creative Thinking Skill by Considering Numerical Ability. International Journal of Instruction, 12(3), 731-744. https://doi.org/10.29333/iji.2019.12344a 


\section{INTRODUCTION}

Creative thinking skills are extremely important for daily problem solving including solving mathematics problems at the elementary school. Indeed, teachers are suggested to employ the appropriate approach to facilitate students' thinking process. Meanwhile, teaching and learning that occurred only emphasize the application of mathematics formulas and procedures can lead to students' weak reasoning and logic which cannot construct their thinking process (Kusaeri \& Aditomo, 2019). Today's education should have been oriented to the 21 st century education. To equip the students with the competencies needed in the 21 st century, which are known as "four Cs", critical thinking and problem solving, communication and collaboration, and creativity and innovation (Patnership for 21st Century Skills, 2009; Setianingsih, Sa'dijah, \& Rahman, 2017). A new standard is needed for the students to have the competence to meet the requirements of the context of core areas and the theme of learning and innovation skills, such as (1) critical thinking and problem solving, that is, the students are able to use various reasons such as inductive and deductive thinking for various situations using systematic thinking: (2) communicating and collaborating, that is, the students are able to communicate clearly and collaborate with other members in their groups and (3) creativity and innovation, that is, the students are able to think creatively, working creatively and creating new innovations.

One of the approaches to the learning mathematics at elementary school that is Realistic Mathematics Education (RME). RME is an approach in the learning of mathematics that offers a learning strategy by developing concepts through re-innovating the concepts based on the students' experiences and knowledge and helping them to solve mathematical problems (Gravemeijer, 1994; Akgul \& Kahveci, 2016). This is supported by Makonye (2014) who claimed that RME helps learners to see the close relationship between mathematics conceptual knowledge and mathematical procedural knowledge. RME thus helps to diminish mathophobia and thus promotes productive disposition in mathematics which is the most important strand to promote meaningful learning of mathematics. Moreover, RME is assumed to be an effective in developing challenged activities (Karaca \& Özkaya, 2017; Revina \& Leung, 2018). Furthermore, HeuvelPanhuizen reformulate six principles of RME: activity, reality, hierarchy, interconnection, interaction and guidance principles. Every principle has interconnections in guiding the students in learning mathematics meaningfully (Heuvelpanhuizen \& Drijvers, 2014 ).

The use of RME approach in the learning of mathematics has been effective to enhance students' activity and their motivation in mathematics. A study done by Arsaythamby and Zubainur (2014) claims that RME can increase student's activity in learning mathematics in which through real contexts the students can construct their knowledge well through the teacher's guidance. Similarly, a study conducted by Zakaria and Syamaun (2017) reported that RME is better than conventional learning in terms of students' activity and their thinking process. Besides that, RME helps students to increase their affective factors, such as motivation, positive collaborative relationship 
among students develop harmonious relations among students and between teacher and students (Ekowati, et al., 2015; Saleh, Prahmana, \& Isa, 2018).

The description of RME approach in solving creativity problem that is oriented toward students' creative thinking is also supported by a learning model to handle the same problems that is oriented toward the development of students' creative thinking skill. The model is Treffinger learning model. This model contains creative learning techniques through steps that are arranged in three levels, that is, basic tools, practice with process, and working with problem (Munandar, 2002; Nisa, 2011). Treffinger's opinion that creativity thinking is a process of learning that attempts to find a creative learning process which is the process of learning that attempts to make the learning process as communicatively as possible to transform the learning situation into a comfortable one to make the learning situation become comfortable to the students (Treffinger, 1986).

Students' success is also determined by internal and external factors. Approach and learning model as external factors meanwhile internal factor related students' numeric ability. Numeric ability is an ability to handle the computation, pattern and logical thinking and scientific (Chen \& Gardner, 2009). This is strengthened by research finding (Muntiari, Candiasa, \& Dantes, 2013) who claimed that there is an interaction between RME approach and numeric ability. This means that numerical ability has a vital role in developing students' mathematic achievement. Thus, numeric ability as student's internal factor which affect toward creative thinking skill which is eligible to be controlled to know the pure effect from Treffinger creative learning model with RME principles.

Although previous researchers present convincing evidence that Treffinger creative learning model could develop students' creative thinking skill for adult learners, meanwhile, as it is widely convinced that RME approach is a suitable to be applied for teaching mathematics at elementary school students, then, it is important to investigate the effect of Treffinger creative learning model with principles of RME approach is integrated. The concept of the integration between Treffinger creative learning model with RME principles has not been conducted by researchers. Due to the characteristic of mathematics is an abstract, mathematics learning at the elementary school must be done by using realistic approach, but, it is conducted with creative strategy. Hence, the integration between Treffinger creative learning model with RME principles is an essential to be considered. In this paper, the concept of this integration is highly supported.

\section{Research Focus}

The aims of this study were : 1) to analyze the difference in creative thinking skill between the students who learned mathematics through Treffinger creative learning model with RME principles and those who learned mathematics through the conventional learning model ; 2) to analyze the difference in creative thinking skill between the students who learned mathematics through Treffinger creative learning model with RME principles and those who learned mathematics through the 
conventional learning model; and 3) to find out the contribution of numeric ability to the students' creative skill.

\section{CONTEXT AND REVIEW OF LITERATURE}

\section{Treffinger Creative Learning Model}

Regarding to the orientation of creative and innovative learning, Donald J. Treffinger, in his book entitled Encouraging Creative Learning for The Gifted and Talented, said that creative learning is learning process that attempt a communicative teaching and learning process which is possible to create enjoyable learning atmosphere for students (Treffinger,1980). The students' creative thinking abilities which are different from one another require a learning condition involving a learning experience, so that the potential of creative thinking can develop. All students of different academic abilities can develop their creative thinking skills, if the learning environment provides an opportunity for the development of these thinking skills (Yusnaeni, Corebima, Susilo, \& Zubaidah, 2017). In this learning, the material is presented through a game, discussion, role-play, demonstration, and assignment. Learning model which is oriented to the building of creative thinking skill is Treffinger learning model.

Treffinger's creative learning model accommodates learning creative techniques through the learning steps which is arranged in the three stages that is basic tools, practice with process, and working with problem (Munandar, 2002; Nisa, 2011). First stage is basic tools which covers a number of techniques as the basic for creative learning. The learning activity at this stage is propose the real students' problem which is based upon their experience and knowledge level, so students involve promptly in the meaningful learning with an answer in various solutions. Second stage, practice with process, that is students are given an opportunity to employ the skill which they got from stage I in the situation practice. And third stage, working with problem, that is employ the skills they got from previous stages toward the real-world challenge. Here, students use the ability through meaningful ways for their life.

The important steps in Treffinger creative learning model are 1) accommodating a variety of new ideas and seeing as many ways as possible to solve problems; 2) using ideas that involve thinking process and feeling; 3) using the creative feeling and thinking to solve problems (Darminto, 2013). The use of Treffinger model in learning has been supported by two study findings (Alfuhaigi, 2015) who concluded that the use of Treffinger learning model gives a positive contribution to the development or improvement in the students' creative thinking and mathematical problem solving. In addition, Treffinger creative learning model can be implemented in education, starting from elementary to university.

\section{Realistic Mathematics Education (RME) Principles}

Realistic Mathematics Education (RME) is a mathematic learning approach that has been developed by Freudenthal in Holland. According to Gravemeijer (1994) realistic mathematics education is rooted in Freudenthal's interpretation of mathematics as an activity. Gravemeijer's idea indicates that Realistic Mathematics Education (RME) has 
been developed based upon Freudenthal's notion which highlights that mathematic as activities. The activities cover problem solving, find problem and organize core issue, which claimed by Freudenthal those as mathematization. RME is mathematics learning by using realistic approach which stimulate students more interest in learning mathematics due to nearby the students' real life.

In the context of this research, the steps used in the mathematics learning employed RME principles which have been developed by Marja van den Heuvel-Panhuizen. Heuvel-Panhuizen reformulate six principles of RME: activity, reality, hierarchy, interconnection, interaction and guidance principles (Heuvel-panhuizen \& Drijvers, 2014). The activity principle focuses on students are treated as active participants in the learning process, the activities are dominantly done by students and the reality principle proposes the learning activity gets closer with students "real-life" problems. Moreover, the level principle underlines that learning mathematics means students should pass various levels of understanding: from informal context-related solutions, through creating various levels of shortcuts and schematizations, to acquiring insight into how concepts and strategies are related. Next, in the intertwinement principle concerns to the mathematical content domains such as number, geometry, measurement, and data handling are not viewed as isolated curriculum chapters but as heavily integrated. Students are offered lots of problems in which they can use their various mathematical tools and knowledge. Furthermore, the interactivity principle means that learning mathematics is not only an individual activity but also a social activity, then the guidance principle refers to Freudenthal's idea of "guided re-invention" of mathematics.

\section{Treffinger Creative Learning Model with RME Principles}

Treffinger creative learning model with RME principles in this study is an instruction that is deliberately designed by combining the stages in Trefffinger creative learning model and RME principles. The three stages in Treffinger creative learning model and the six principles of the RME will collaborate with that result in the following integration: the basic tools stage uses reality principle and activity that will guide the students to the development of creative thinking skill in the fluency aspect. The practice and process stage uses the principle of interaction and principle of reality that directs the students to the development of creative thinking skill in the originality aspect. While, the working with problems stage uses the principle of guidance, the principle of hierarchy, the principle of interconnection that are assumed to be oriented to the development of creative thinking skill in the flexibility aspect. The syntax result of integrated Treffinger creative learning model with RME principles is the researchers own development which was not investigated previously. From the result of the collaboration a new syntax of Treffinger creative learning model with RME principles is formed with the details of its steps as shown in Table 1. 
Table 1

The Syntax of Treffinger Creative Learning Model with RME Principles

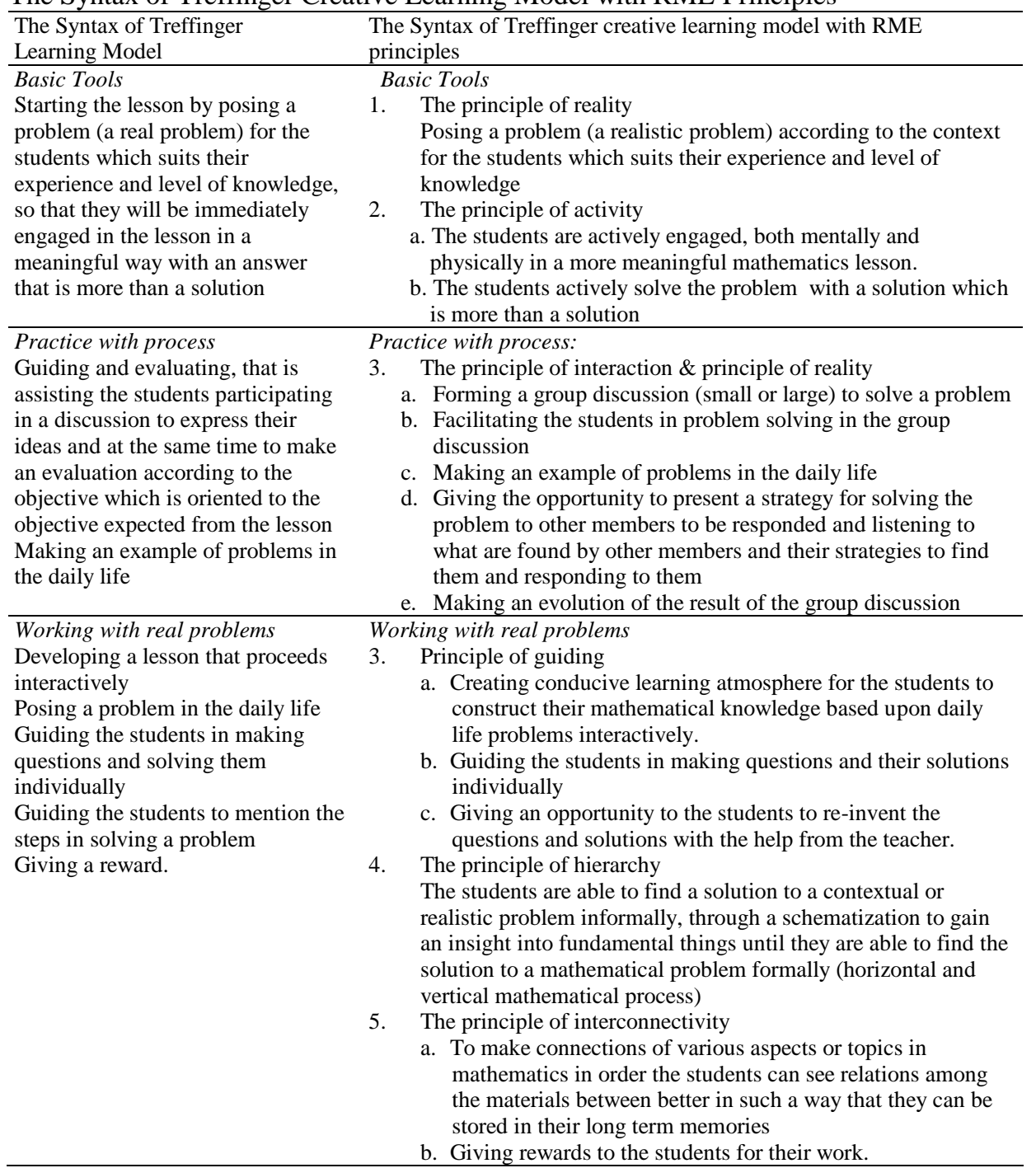

\section{Creative Thinking Skill}

Innovations in learning practices, especially in developing creativity are still relatively rare. On the other hand, creativity is an important component in learning and helps individuals in solving their problems in daily life (Saavedra \& Opfer, 2012). Torrance (Mann, 2006; Scott, 2015) relates creativity to moral commitment, self-confidence, 
ability to see problems from different perspectives, and ability in finding different solutions. Darminto (2013), for example, states that creativity is an ability to find ideas and new symbols, in improvizing stable ideas and symbols, reorganizing them into new ones. Similarly, Honeck (2016) argue that creativity is an effort to relate objects or ideas which were previously unrelated. Thus, creativity is able to make people think creatively. According to Hwang, Chen, Dung \& Yang (Runish, Herman, \& Dahlan, 2016) creative thinking is one of the types of thinking that is oriented toward the attainment of new insights, new approaches, new perspective or new ways in understanding something.

The components of creative thinking skill are fluency, flexibility, and originality (Alfuhaigi, 2015; Honeck, 2016; Mann, 2006; Sriwongchai, Jantharajit, \& Chookhampaeng, 2015; Vale \& Barbosa, 2015). Fluency refers to the facility to produce many ideas during the creative thinking process. Flexibility refers to the ability to leave the old way of thinking and adopt new ideas or ways of thinking. Flexibility is also shown by the variety of the ideas developed. On the other hand, originality refers to the ability to produce unpredictable or unique ideas. Creativity and innovation will become increasingly more developed if the student has a unique opportunity to use divergent thinking (Scott, 2015). The students have to think outside of the existing habits, involving new ways of thinking, obtaining opportunities to communicate new ideas and solutions, asking uncommon questions, and attempting to give assumed answers.

\section{Numerical Ability}

Logical-mathematical intelligence involves numerous components: mathematical calculation, logical thinking, problem-solving, deductive and inductive reasoning, and the discernment of patterns and relationship. They are mathematical computation, thinking logic, problem solving, deductive and inductive reasonings and ability to differentiate patterns and relations. The components are very important in mathematics learning at school (Brualdi, 1996).

Numerical ability is the ability to handle numbers and mathematical computation, patterns and logical and scientific thinking. Gardner states that logic-mathematical ability is the ability to manage a long thinking chain. This intelligence covers the ability to process numbers, mathematics, and other things that are related to number (Roesdiyanto, 2014). Numerical ability is one of the factors that supports the attainment of the students' creative thinking skill, that is, speed and carefulness in doing the computation. All activities in learning mathematics are based on counting ability for the students with a high numeric ability they tend to be quicker in doing the counting operation than those with a low numerical ability (Pica, Marhaeni, \& Dantes, 2015) Hence, in the Treffinger creative learning model with RME principles that tends to involve students actively in groups will obviously favor the students with a high numeric ability. However, in the conventional learning model, the students with a high numeric ability will feel comfortable when taught in that way. Thus, in this study it is assumed that numeric ability has a strong correlation with creative thinking skill so that it is appropriate that it is controlled to see the pure effect of Treffinger creative learning model with RME principles on the students' creative thinking skill. 


\section{METHOD}

\section{Design}

This study was a quasi-experiment research with post-test only control group design. The study was aimed at investigating the difference in creative thinking skill between the experiment group and the control group. The experiment group was treated with Treffinger creative learning model with RME principles while the control group was treated with the conventional learning model. This study consisted of three stages, i.e., pre-experiment, experiment, and post-experiment. The treatment was done in eight meetings, both for the experiment group and the control group which was then ended with a posttest to measure the students' creative thinking skill.

\section{Population and Sample}

The population of this study consisted of all the fifth-grade students throughout Lelak district with the total of 11 schools $(n=383)$. The sampling was done using random sampling technique. The sample of the study consisted of SDI Watu Weri and SDN Weri Pateng $(\mathrm{n}=101)$. SDI Watu Weri was used as experiment group and SDI Weri Pateng as control group. During the treatment the students solved problems, both individually and in group using student's worksheet in the topic of fraction operation.

\section{Data Collection and Analysis}

Data in this study were obtained from the scores in numeric ability and creative thinking skill of the students. For the assessment rubric (La Moma, 2015) with the 0-4 scale was used. Content validity test instruments used were validated by 5 experts with analyzed by using CVR (content validity ratio) which has been developed by Lawshe (Lawshe, 1975 ) and their validity and reliability have been tested using validity test and reliability test. The creative thinking skill test has 5 essay items (reliability $=0.891$ ) and the numeric ability test has 35 multiple choice items (reliability $=0.79$ ). The data were analyzed using the Analysis of Covariate (ANCOVA) that was preceded by the assumption tests, i.e., distribution normality test and group homogeneity variance test aided with Statistical Package for the social Sciences (SPSS) for windows version 23.0.

\section{FINDINGS}

The hypotheses tested in this study were 1) the creative thinking skill of the students who learned mathematics through Treffinger creative learning model with RME principles is higher than that of those who learned mathematics through the conventional learning model; 2) the creative thinking skill of the students who learned mathematics through Treffinger creative learning model with RME principles is higher than that of those who learned through the conventional learning model, after numeric ability is controlled, and 3) there is a contribution of numeric ability to the students' creative thinking skill. The result of descriptive statistical analysis can be seen from Table 2 . 
Table 2

Recap of Descriptive Statistical Analysis

\begin{tabular}{llllllllll}
\hline Variable & Group & $\mathrm{N}$ & Mean & Median & Stand.De. & Var & Range & Min & Max \\
\hline Numeric Ability & Experiment & 51 & 68.78 & 69 & 7.37 & 54.33 & 34 & 46 & 80 \\
& Control & 50 & 68.52 & 69 & 7.29 & 53.15 & 32 & 51 & 83 \\
\hline Creative & Experiment & 51 & 67.84 & 70 & 10.87 & 18.25 & 45 & 40 & 85 \\
Thinking Skill & Control & 50 & 58.8 & 60 & 9.98 & 9955 & 40 & 35 & 70 \\
\hline
\end{tabular}

Based on the data in Table 2 above, it can be said that the mean score for creative thinking ability of the students who learned mathematics through Treffinger creative learning model with RME principles is higher than those who learned mathematics through the conventional learning model. Then, assumption tests were conducted, i.e., data distribution normality test, data group variance homogeneity test, and data linearity test. Based on the result of the assumption tests was obtained that the sig values of the data are higher than 0.05 . Thus, it can be said that the data have a normal distribution, homogeneous variance and have a linear regression. To test the first hypothesis T-test was used, result of variance analysis using SPSS 23.0 can be seen in Table 3 below.

Table 3

Recap of Variance Analysis

\begin{tabular}{llllll}
\hline \multicolumn{7}{c}{ Tests of Between-Subjects Effects } \\
\hline Source & Type III Sum of Squares & df & Mean Square & F & Sig. \\
\hline Corrected Model & $2064.700^{\mathrm{a}}$ & 1 & 2064.700 & 23.794 & $<001$ \\
Intercept & 404932.027 & 1 & 404932.027 & 4.6663 & $<001$ \\
Learning model & 2064.700 & 1 & 2064.700 & 23.794 & $<001$ \\
Error & 8590.745 & 99 & 86.775 & & \\
Total & 416200.000 & 101 & & & \\
Corrected Total & 10655.446 & 100 & & & \\
\hline a. R Squared $=0.194$ (Adjusted R Squared $=0.186)$ \\
\hline
\end{tabular}

References to analysis it was obtained that $\mathrm{F}_{\text {obs. }}=23.794$ and sig. value $<0.001$. Since sig $<0.05$, then it can be concluded that the creative thinking skill of the students who learned mathematics through Treffinger creative learning model with RME principles is higher than that of those who learned through the conventional learning model. The result of the testing of the second hypothesis can be seen in Table 4 below.

Table 4

Recap of the Covariate Analysis

\begin{tabular}{llllll}
\hline \multicolumn{7}{c}{ Tests of Between-Subjects Effects } \\
\hline Source & Type III Sum of Squares & df & Mean Square & F & Sig. \\
\hline Corrected Model & $6772.207^{\mathrm{a}}$ & 2 & 3386.104 & 85.454 & $<0.001$ \\
Intercept & 185.286 & 1 & 185.286 & 4.676 & 0.033 \\
Numeric Ability & 4707.507 & 1 & 4707.507 & 118.802 & $<0.001$ \\
Learning Model & 1927.079 & 1 & 1927.079 & 48.633 & $<0.001$ \\
Error & 3883.238 & 98 & 39.625 & & \\
Total & 416200.000 & 101 & & & \\
Corrected Total & 10655.446 & 100 & & & \\
\hline a. R Squared $=.636$ (Adjusted R Squared =.628)
\end{tabular}


Based upon data described above table, it is obtained that the Fvalue $=48.633$ and sig $=$ 0.001 . By looking at the sig value $<0.05$ it means that the students' creative skill of the students who learned mathematics through Treffinger creative learning model with RME principles is higher than that of those who learned mathematics through the conventional learning model, after numeric ability is controlled. The multitude of the contribution of numeric ability to creative thinking can be seen in Table 5 .

Table 5

Contribution of Numerical Ability

\begin{tabular}{lllll}
\hline \multicolumn{4}{c}{ Model Summary } \\
\hline Model & $\mathrm{R}$ & R Square & Adjusted R Square & $\begin{array}{l}\text { Std. Error of the } \\
\text { Estimate }\end{array}$ \\
\hline 1 & $.582^{\mathrm{a}}$ & .338 & .332 & 5.90718 \\
\hline a. Predictors: (Constant), Numeric ability & \\
\hline
\end{tabular}

Then the result of analysis shows that numeric ability gives a $0.332 \times 100 \%=33.2 \%$ contribution to students' creative thinking skill. This means that a variation in creative thinking skill is around $33.2 \%$, which can be accounted for by the numeric ability covariate, and the rest by other variables that were not investigated.

\section{DISCUSSION}

The main aim of this study was to get a description of the effect of Treffinger creative learning model with RME principles on the students' creative thinking skill with numeric ability as covariable. The result of the study shows that Treffinger creative learning model with RME principles has a significant effect on the students' creative thinking skill after the students' numeric ability is controlled. This result confirms the study done by Rohaeti and Priatna (2017); Nisa (2011) that concluded that Treffinger model can give a positive contribution to the development of students' creative thinking skill and mathematical problem solving ability.

This finding proves that Treffinger creative learning model with RME principles gives a positive effect on the development or an increase in the students' creative thinking skill. The positive effect is obviously influenced by the three stages of the Treffinger learning model that is integrated with the six principles of RME. In conformity to the study by Arsaythamby \& Zubainur (2014); Zakaria \& Syamaun (2017), this study concludes that Treffinger RME approach is better than conventional approach. This study result also supports Treffinger's opinion that creative thinking is a process of learning that attempts to find a creative learning process which is the process of learning that attempts to make the learning process as communicatively as possible to transform the learning situation into a comfortable one to make the learning situation become comfortable to the students (Treffinger, 1986).

At the basic tools stage that uses the principle of reality and the principle of activity, here the students are able to make a realistic problem that is related to addition and subtraction, multiplication and division of fractions with using their own ways based on the knowledge that they have. The basic tools stage by using the principle of reality and 
the principle of activity can guide the students toward the development of creative thinking skill in the proficiency aspect. Here the students are able to solve problems well and when they get stuck they will ask for help from their peers who are more able or the teacher. This is in line with Vygotsky's ZPD concept that states that ZPD (zone of proximal development) is the zone in which the students cannot finish difficult tasks to be mastered by themselves, but can be mastered using guidance and help from adults or more able students. In this case, ZPD is a distance between the level of real development shown in the ability to solve problems alone and the level of the potential development ability shown in the ability to solve problems with the help from adults or by working together with more able peers (Christmas, Kudza, \& Josiah, 2013; Siyepu, 2013).

Then, at the practice with process stage by using the principle of interaction, the students are able to cooperate with the team members in a large group to finish the task assigned and the problem constructed by the students themselves using different ways than the usual way. The practice with process stage directs the students toward the formation of creative thinking skill in the aspect of originality. This process refers to Vygotsky's constructivist theory in which learning is the most effective when the students can relate what they learn to the environment and by creating meanings from different experiences (Sze-yeng, Maznah, \& Hussain, 2010; Zain, Rasidi, \& Abidin, 2012).

While at the stage of working with real problem, this stage is integrated with the principle of guidance, the principle of hierarchy and the principle of interconnectivity. At this stage, through guidance, the students can solve the problems using more than one way. At this stage, the students are able to find a solution to a realistic problem informally, through schematization and get an insight into fundamental things until they are able to find a solution to a mathematical problem formally (the horizontal and vertical mathematizations). The emphasis here is that the students think creatively with a variety of problem solutions according to their ability, using their own ways according to the conceptual and procedural knowledge that they have. The working with real problem stage directs the students to the formation of creative thinking skill in the flexibility aspect. The process of problem solving using this stage starts from the concrete stage to the abstract. This is in conformity with Piaget's view that the elementary school aged students (7-12) are at the concrete operational phase and the knowledge is developed in the child's mind through the process of assimilation and accommodation (Richland, Frausel, \& Begolli, 2016).

\section{CONCLUSION}

The research finding supported the theory and the previous researches stating that implementation of Treffinger creative learning model with RME principles effective toward students' creative thinking skills. The findings of this study showed that 1) the creative thinking skill of the students who learned mathematics through Treffinger creative learning model with RME principles was higher than that of those who learned through the conventional learning model; 2) the creative thinking skill of the students who learned through Treffinger creative learning model with RME principles was higher than that of those who learned through the conventional learning model after 
controlling numerical ability; and 3) there was a 33,2\% contribution of numeric ability to the students' creative thinking skill. Based upon the findings, this research strongly recommended to be continued on the subject of fraction or other materials at primary schools.

\section{REFERENCES}

Akgul, S., \& Kahveci, N. G. (2016). A study on the development of a mathematics creativity scale. Eurasian Journal of Educational Research, 62, 57-76. http://dx.doi.org/10.14689/ejer.2016.62.5.

Alfuhaigi, S. S. (2015). School environment and creativity development: a review of literature. Journal of Educational and Instructional Studies in the World, 5(2), 33-38.

Ardana, I. M., Ariawan, I. P. W., \& Divayana, D. G. H. (2017). Measuring the effectiveness of BCLS model (Bruner, local culture, scaffolding) in mathematics learning by using expert system-based CSE-UCLA. International Journal of Education and Management Engineering, 7(4), 1-12. https://doi.org/10.5815/ijeme.2017.04.01.

Arsaythamby, V., \& Zubainur, C. M. (2014). How a realistic mathematics educational approach affects students' activities in primary schools? Procedia-Social and Behavioral Sciences, 159, 309-313. https://doi.org/10.1016/j.sbspro.2014.12.378.

Brualdi, A. C (1996). Multiple intelligence: Gardner's theory, practical assessment, research \& evaluation. Eric Clearing house on assessment and Evaluation, 5(10), Retrieved from https://pareonline.net/getvn.asp?v=5\&n=10.

Chen, J., Moran, S., \& Gardner, H. (2009). Multiple intelligences around the word. New York, NY: Jossey-Bass.

Christmas, D., Kudzai, C., \& Josiah, M. (2013). Vygotsky's zone of proximal development theory: What are its implications for mathematical learning? Greener Journal of Social Science, 3(7), 371-377.

Darminto, B. P. (2013). Improving the ability of students' mathematical problem solving. Jurnal Pendidikan Matematika Dan Sains, 1(2), 101-107.

Ekowati, C. K., Ardi, M., Darwis, M., Pua, H. M. D., Tahmir, S., \& Dirawan, G. D. (2015). The application of RME approach in learning mathematics in Penfui Kupang. International Journal of Education and Information Studies, 5(1), 35-43.

Gravemeijer, K. P. (1994) Developing realistic mathematics education. Utrecht: Freudenthal Institute.

Heuvel-Panhuizen, M. Van Den, \& Drijvers, P. (2014). Realistic mathematics education. Encyclopedia of Mathematics Education, 521-534. https://doi.org/10.1007/978-94-007-4978-8

Honeck, E. (2016). Inspiring creativity in teachers to impact students. Torrance Journal for Applied Creativity, 1, 33-38. 
Karaca, S. Y., \& Özkaya, A. (2017). The effects of realistic mathematics education on students' math self-reports in fifth grades. International Journal of Curriculum and Instruction, 9(1), 81-103.

Kusaeri, \& Aditomo, A. (2019). Pedagogical beliefs about critical thinking among Indonesian mathematics pre-service teachers. International Journal of Instruction, 12(1), 573-590. https://doi.org/10.29333/iji.2019.12137a

La Moma. (2015). Pengembangan instrumen kemampuan berpikir kreatif matematis. Delta-Pi: Journal Matematika Dan Pendidikan Matematika, 4(1), 27-41. Retrieved from http://garuda.ristekdikti.go.id

Mann, E. L. (2006). Creativity: The essence of mathematics. Journal for the Education of the Gifted, 30(2), 236-260. https://doi.org/10.4219/jeg-2006-264.

Munandar, U. (2002). Kreativitas dan Keberbakatan. Jakarta: PT Gramedia Pustaka Utama.

Muntiari, N. W., Candiasa, I. M., \& Dantes, N. (2013). Pengaruh pendekatan pembelajaran matematika realistik terhadap prestasi belajar ditinjau dari kemampuan numerik siswa. E-Journal Program Pascasarjana Universitas Pendidikan Ganesha, 4, $1-11$.

Nisa, T. F. (2011). Pembelajaran Matematika dengan Setting Model Treffinger Untuk Mengembangkan Kreativitas Siswa. Pedagogia, 1(1), 35-48.

Patnership for 21st Century Skills. (2009). P21 framework definitions. Washington: Pearson.

Pica, I.W, Marhaeni, A. A. I. N., \& Dantes, R. (2015). Pengaruh penerapan pendidikan matematika realistik terhadap hasil belajar matematika dengan kovariabel kemampuan numerik" e- Journal Program Pascasarjana Universitas Pendidikan Ganesha, 5, 1-12.

Revina, S., \& Leung, F. (2018). Educational borrowing and mathematics curriculum: Realistic Mathematics Education in the Dutch and Indonesian primary curriculum. International Journal on Emerging Mathematics Education, 2(1), 1-16. https://doi.org/http://dx.doi.org/10.12928/ijeme.v2i1.8025.

Richland, L. E., Frausel, R. R., \& Begolli, K. (2016). Cognitive development. In: The SAGE Encyclopedia of Theory in Psychology. Thousand Oaks: SAGE Publication, inc. https://doi.org/10.4135/9781483346274.n50

Roesdiyanto. (2014). Learning model of physical education using multiple inelegancies approaches and influence on social and environmental development. Global Journal of Human Science, 14(6), 50-55.

Rohaeti, Priatna, D. (2013). Penerapan model Treffinger pada pembelajaran matematika untuk meningkatkan kemampuan berpikir kreatif siswa SMP. Retrieved from Portalgaruda.Org/Article.Php?

Runisah, Herman, T., \& Dahlan, J. A. (2016). The enhancement of students' creative 
thinking skills in mathematics through the 5e learning cycle with metacognitive technique. International Journal of Education and Research, 4(7), 347-360.

Saavedra, A. R., \& Opfer, V. D. (2012). Partnership for global learning. In Learning and Learning 21 st century Skills: Lessons from the Learning Sciences. Sydney: Rand Corporation.

Saleh, M., Prahmana, R.C.I., \& Isa, M. (2018). Improving the reasoning ability of elementary school student trough the Indonesia realistic. Journal on Mathematics Education, 9(1), 41-54.

Scott, C. L. (2015). The futures of learning 3: What kind of pedagogies for the 21st century? Education Research and Foresight Working Papers, 15, 1-15.

Setianingsih, R., Sa'dijah, C., \& Rahman, A. (2017). Investigating fifth-grade students' construction of mathematical knowledge through classroom discussion. International Electronic Journal of Mathematics Education, 12(3), 383-396.

Siyepu, S. (2013). The zone of proximal development in the learning of mathematics. South African Journal of Education, 33(2), 1-13.

Sriwongchai, A., Jantharajit, N., \& Chookhampaeng, S. (2015). Developing the Mathematics learning management model for improving creative thinking in Thailand. International Education Studies, 8(11), 77-87. https://doi.org/10.5539/ies.v8n11p77

Sze-yeng, F., Maznah, R., \& Hussain, R. (2010). Self-directed learning in a socioconstructivist learning environment. Procedia-Social and Behavioral Sciences, 9, 1913-1917. https://doi.org/10.1016/j.sbspro.2010.12.423

Treffinger, D. J., (1986). Research on creativity. Gifted child quarterly, 30(1), 15-19. https://doi.org/10.1177/001698628603000103.

Treffinger D. J. (1980) Encouraging creative learning for the gifted and talented: A handbook of methods and techniques. Ventura: Ventura Country Superintendent of School Office.

Vale, I., \& Barbosa, A. (2015). Mathematics creativity in elementary teacher training. Journal of the European Teacher Education Network, 10, 101-109.

Yusnaeni, Corebima, A. D., Susilo, H., \& Zubaidah, S. (2017). Creative thinking of low academic student undergoing search solve create and share learning integrated with metacognitive strategy. International Journal of Instruction, 10(2), 245-262. https://doi.org/10.12973/iji.2017.10216a

Zain, S. F. H. S., Rasidi, F. E. M., \& Abidin, I. I. Z. (2012). Student-centred learning in mathematics-constructivism in the classroom. Journal of International Education Research, 8(4), 319-328.

Zakaria, E., \& Syamaun, M. (2017). The effect of realistic mathematics education approach on students' achievement and attitudes towards mathematics. Mathematics Education Trends and Research, 1, 32-40. https://doi.org/10.5899/2017/metr-00093. 